\title{
MAKAM SENIMAN: PERKEMBANGAN IDENTITAS PEMAKAMAN DI ERA MODERN
}

\author{
Benny Afwadzi \\ Universitas Islam Negeri Maulana Malik Ibrahim Malang \\ Jl. Gajayana No. 50 Malang Jawa Timur, Indonesia \\ E-mail: afwadzi@pai.uin-malang.ac.id
}

\begin{abstract}
The paper examines the development of grave identity in the modern era, which focuses on Taman Makam Seniman dan Budayawan Giri Sapto, which is located on Gajah hill, Giri Rejo village, Imogiri sub-district, Bantul district, Daerah Istimewa Yogyakarta. The grave that full of art elements is very interesting because it is devoted to artists and cultural observers and also does not recognize the exclusivity of certain religions, becomes a tourist destination in Yogyakarta, and is mentioned as the only one in the world. This study used field research, with qualitativedescriptive methods and data collecting techniques in the form of observation, interviews, and documentation. The author finds that the artists' grave (Makam Seniman) are grave with a characteristic exclusivity of certain professions (artists) and also store interesting artistic elements, namely the existence of several gravestones with unique shapes which symbolizes the art field of the deceased when it was still alive, the artwork displayed on the grave, and the funeral ceremony combined with art. Seeing the phenomena that created from this grave, it can be said that there has been a form of grave identity development in modern times due to the development of human culture, which in the context of the artists' grave is realized by art. Artists' grave essentially contains the development of identity as a grave place, which previously had appeared a grave with a model of religious identity, Pancasila (multi religions), heroes, kingdoms, and even pesantren. This type of grave identity with the model that is following a profession or a field that occupied by someone can be said to become a characteristic of the modern grave culture.Keywords:
\end{abstract}

Keywords:

Artistic; artists' grave; identity development.

\begin{abstract}
Abstrak
Tulisan ini mengkaji tentang perkembangan identitas pemakaman di era modern, yang memfokuskan pada Taman Makam Seniman dan Budayawan Giri Sapto, yang terletak di bukit Gajah, desa Giri Rejo, kecamatan Imogiri, kabupaten Bantul, Daerah Istimewa Yogyakarta. Makam yang sarat unsur seni ini sangat menarik karena dikhususkan untuk para seniman dan budayawan dan tidak mengenal eksklusivitas agama tertentu, menjadi destinasi wisata di Yogyakarta, dan disebutkan sebagai satu-satunya yang terdapat di dunia. Dengan metode kualitatifdeskriptif dan teknik pengumpulan data berupa observasi, wawancara, dan dokumentasi, penulis menemukan bahwa Makam Seniman merupakan makam dengan ciri khas eksklusivitas profesi tertentu (seniman) dan juga menyimpan unsur-unsur artistik yang menarik, yaitu adanya beberapa nisan dengan bentuk unik yang menyimbolkan bidang kesenian almarhum tatkala masih hidup, hasil karya seni yang dipajang di makam, dan adanya upacara pemakaman yang dibalut dengan kesenian. Melihat fenomena yang tercipta dari makam ini, bisa dikatakan telah terjadi sebuah bentuk perkembangan identitas pemakaman pada masa modern akibat adanya perkembangan kebudayaan manusia, yang dalam konteks Makam Seniman diwujudkan oleh kesenian. Makam Seniman pada hakikatnya memuat perkembangan jati diri sebagai sebuah tempat pemakaman, yang sebelumnya telah muncul makam dengan model identitas agama, Pancasila, pahlawan, kerajaan, dan bahkan pesantren. Jenis identitas makam dengan model seperti ini, yakni mengikuti profesi atau bidang yang ditekuni seseorang boleh dikatakan menjadi ciri khas kebudayaan pemakaman pada masa modern.
\end{abstract}

\section{Kata Kunci:}

Artistik; makam seniman; perkembangan identitas. 


\section{A. PENDAHULUAN}

Dalam konteks keindonesiaan, terdapat sebuah makam yang mempunyai nilai artistik dan keunikan tersendiri, yang tidak ditemukan di tempat lain. Ia bernama Taman Makam Seniman dan Budayawan Giri Sapto Imogiri Bantul Yogyakarta (selanjutnya disebut Makam Seniman), yang terletak di sebelah Makam Raja-Raja Mataram. Pemakaman ini sangat unik dan berbeda dengan pemakaman pada umumnya. Pertama, kompleks Makam Seniman dikhususkan untuk para seniman dan budayawan saja dan tidak mengenal eksklusivitas agama tertentu. Penganut agama apapun diperbolehkan dimakamkan di sini, asalkan ia berprofesi sebagai seniman atau budayawan. Kedua, kompleks makam ini juga menjadi salah satu destinasi wisata yang ada di Yogyakarta. Ini merupakan fenomena yang cukup langka mengingat makam selalu diidentikkan dengan keangkeran atau keseraman. Jikalau sebagai wisata rohani pun, biasanya diarahkan pada makam yang mempunyai tokoh dengan kedudukan spiritual, keagamaan, atau kemasyarakatan yang tinggi, akan tetapi hal itu ternyata tidak ditemukan di kompleks makam ini. Ketiga, jenis makam seperti ini merupakan satu-satunya di dunia dan tidak akan ditemukan di belahan bumi yang lain. Tidak mengherankan jika Yani Sapto Hoedojo, istri dari pendiri Makam Seniman Sapto Hoedojo - menuturkan bahwa Taman Makam Seniman dan Budayawan di Imogiri ini merupakan satu-satunya yang ada di dunia. ${ }^{1}$

Keberadaan makam dengan karakteristik seperti disebutkan di atas secara kultural cukup menghentak. Pasalnya, bagi masyarakat Islam Jawa, makam pada hakikatnya merupakan salah satu lokus sakral dalam kehidupan manusia. Makam bisa mempertemukan berbagai pihak sosial, yang dalam konsepsi kebudayaan disebut sebagai cultural sphere. Kaum abangan dan santri tradisional (NU) dapat dipertemukan dalam lokus makam. ${ }^{2}$

\footnotetext{
${ }^{1}$ Barata, "Peresmian Patung Sapto Hoedojo di Makam Seniman," Tembi News, t.t.

2 Nur Syam, Madzhab-Madzhab Antropologi (Yogyakarta: LKiS, 2009), 117.
}

Makam dianggap sebagai tempat suci dan pantas dihormati, sehingga mengundang orang untuk berziarah dengan berbagai motivaasi. ${ }^{3}$ Nilai sakral dan suci seperti itu juga dimiliki oleh "tetangga" Makam Seniman, yaitu Makam Raja-Raja Mataram. Ia kental dengan adat dan tradisi Jawa serta penuh dengan ritual-ritual tertentu. ${ }^{4}$ Namun, kenyataan itu berseberangan dengan Makam Seniman. Dengan diciptakannya makam dengan balutan kesenian seakan melunturkan nilai-nilai sakralitas sebuah makam. Ia tidak ubahnya seperti sebuah karya seni yang menyimpan nilai-nilai artistik, hanya saja berwujud dalam bentuk sebuah makam.

Melihat aspek-aspek yang menarik dari Makam Seniman sebagaimana dituturkan di atas itulah, sangat penting untuk menelaah lebih jauh bagaimana unsur seni terangkum dalam makam ini. Kemudian, fenomena tersebut akan dianalisis sebagai sebuah kebudayaan yang mengalami perkembangan identitas. Artikel ini boleh dikatakan sebagai kajian awal karena belum ditemukan - sejauh penelusuran penulis - karya ilmiah yang fokus membahas fenomena Makam Seniman ini. Di sisi lain, Makam Raja-Raja Mataram yang berada di dekatnya sudah dikaji dalam beberapa penelitian, seperti Unsur Religi dalam Tradisi Nguras Enceh di Makam Raja-

${ }^{3}$ M Misbahul Mujib, "Fenomena Tradisi Ziarah Lokal dalam Masyarakat Jawa: Kontestasi Kesalehan, Identitas Keagamaan dan Komersial,' IBDA : Jurnal Kajian Islam dan Budaya 14, no. 2 (2 Oktober 2016): 204-224, https://doi.org/10.24090/ibda.v14i2.673.

${ }^{4} \mathrm{Zu}$ Puput Tri Hardiyanti, Wahyudi, Nurodin, Unun Achmad Alimin, "Sinergitas Islam dan Budaya dalam Kearifan Lokal (Studi Kasus Pada Komplek Pemakaman Raja-Raja Imogiri di Desa Panjaitan Imogiri)," EMPIRISMA 26, no. 1 (Juli 2017), doi:10.30762/empirisma.v26i1.683. Paling tidak ada tiga ritual rutin yang dilaksanakan di Makam Raja-Raja Mataram ini, yakni doa bersama di bulan Ruwah (Sya'ban), menguras gentong (enceh) di bulan Suro (Muharram), dan peringatan berdirinya kerajaan. Lihat, Noer Ardiansjah, "Tiga Ritual Rutin di Makam Raja Imogiri," 2016, diakses tanggal 20 Januari 2018, https://merahputih.com. Memasuki area makam ini pun tidak bisa berpakaian bebas, tetapi harus menggunakan pakaian adat Jawa. 
Raja Imogiri oleh Maliky Nur Rokhim; ${ }^{5}$ Motivasi Masyarakat Menghadiri Tradisi Nguras Kong di Makam Raja-Raja Mataram Imogiri oleh Sarjono. ${ }^{6}$

Sebenarnya, kajian terhadap eksistensi makam telah banyak dikaji dalam berbagai penelitian, seperti kajian Uka Tjandrasasmita yang mengkaji kutipan ayat Alquran dan untaian kata sufistik di makam kuno; ${ }^{7}$ Asep Saifullah yang mengkaji inskripsi yang ada di makam raja-raja Mempawah; ${ }^{8}$ Wuri Handoko yang mengeksplorasi tradisi nisan menhir pada makam-makam kuno raja-raja di kerajaan Hitu; ${ }^{9}$ Effie Latifundia yang mengkaji jejakjejak kebudayaan dalam nisan kuno Islam di wilayah Kuningan; ${ }^{10}$ dan Abu Muslim yang mengulas simbol pada makam Syekh Bil Ma'ruf. ${ }^{11}$ Namun yang perlu dipahami adalah bahwa kajian-kajian yang dilakukan itu lebih banyak menggunakan perangkat ilmu arkeologi. Hal ini dapat dimaklumi mengingat makam memang menjadi ladang subur bagi arkeologi, akan tetapi yang harus dimengerti bahwa ilmu tersebut pada dasarnya digunakan untuk mengelaborasi makam-makam kuno atau yang tercipta di masa lalu. Inilah yang

\footnotetext{
${ }^{5}$ Maliky Nur Rokhim, "Unsur Religi dalam Tradisi Nguras Enceh di Makam Raja-Raja Imogiri”, Skripsi (Universitas Negeri Yogyakarta, 2013).

${ }^{6}$ Sarjono, "Motivasi Masyarakat Menghadiri Tradisi Nguras Kong di Makam Raja-Raja Mataram Imogiri”, Skripsi (UIN Sunan Kalijaga Yogyakarta, 2013).

Uka Tjandrasasmita, "Kutipan Ayat-ayat AlQur'an dan Kalimat Sufistik pada Beberapa Batu Nisan Makam Kuno di Indonesia," Suhuf: Jurnal Pengkajian al-Quran dan Budaya 2, no. 2 (2009): 249-270, https://doi.org/10.22548/shf.v2i2.91.

${ }^{8}$ Asep Saefullah, "Inskripsi pada Kompleks Makam Raja-raja Mempawah, Kalimantan Barat," Suhuf: Jurnal Pengkajian al-Quran dan Budaya 5, no. 1 (2012): 77-95, doi:10.22548/shf.v5i1.51.

9 Wuri Handoko, "Tradisi Nisan Menhir pada Makam Kuno Raja-raja di Wilayah Kerajaan Hitu," Kapata Arkeologi 10, no. 1 (April 2016): 33-46, doi:10.24832/kapata.v10i1.216.

${ }^{10}$ Effie Latifundia, "Jejak Budaya pada Nisan Kuno Islam di Kuningan," Al-Turas: Mimbar Sejarah, Sastra, Budaya, dan Agama 21, no. 1 (2015): 30-41.

${ }^{11}$ Abu Muslim, "Simbol pada Makam Syekh Bil Ma'ruf dan Sosio-Religi Pulau Tangnga Sulawesi Barat," Jurnal Lektur Keagamaan 14, no. 2 (31 Desember 2016): 257-80, https://doi.org/10.31291/jlk.v14i2.501.
}

membedakan penelitian-penelitian yang disebutkan tersebut dengan tulisan ini yang menganalisis fenomena makam yang terbentuk di era modern, terlebih lagi makam modern yang bernuansa artistik. Oleh sebab itulah, dalam tulisan ini, pisau analisis yang digunakan adalah ilmu antropologi, yakni ilmu tentang manusia dan kebudayaan yang dihasilkannya. Nantinya, antropologi akan mengungkapkan perkembangan identitas makam sebagai akibat adanya perkembangan kebudayaan manusia.

Tulisan ini merupakan hasil penelitian sebagai follow up Short Course Budaya Islam Diktis tahun 2017 terhadap keberadaan Taman Makam Seniman dan Budayawan Giri Sapto, bukit Gajah, desa Giri Rejo, Kecamatan Imogiri, Kabupaten Bantul, Daerah Istimewa Yogyakarta. Data-data yang disajikan berasal dari hasil pengamatan di awal tahun 2018, yang sebelumnya telah didahului dengan telaah awal pada makam ini di bulan Mei 2013. Oleh karenanya, data dalam penelitian ini merupakan kolaborasi antara tahun 2013 dan tahun 2018. Jika terdapat perubahan data antara tahun 2013 dan 2018, maka yang dituliskan adalah data yang ditemukan pada tahun 2018.

Dengan metode kualitatif-deskriptif dan melalui teknik pengumpulan data berupa observasi langsung, wawancara, dan dokumentasi, penulis berusaha menemukan perkembangan identitas pemakaman, yang didasarkan atas fenomena Makam Seniman. Sebelum mengungkapkan perkembangan tersebut, dijelaskan terlebih dahulu mengenai unsurunsur seni di makam ini sebagai pijakan dalam membahas perkembangan identitas makam. Subjek penelitian ini sendiri terdiri atas beberapa figur, yaitu juru kunci Makam Seniman (Jamzari), kaum warga sekitar Makam Seniman sekaligus juru kunci Makam RajaRaja Mataram (Slamet Abdurrahman), pengunjung makam, dan juga masyarakat yang bertempat tinggal di sekitar makam. 


\section{B. HASIL DAN PEMBAHASAN \\ 1. Sekilas Mengenal Makam Seniman dan Budayawan Giri Sapto \\ a. Sejarah Pendirian Makam Seniman}

Pendirian Makam Seniman merupakan gagasan orisinil dari seorang seniman pelukis putra Solo yang bernama Sapto Hoedojo. Ia dilahirkan di Solo pada 6 Februari 1925, yang merupakan anak ketujuh dari 18 bersaudara keturunan KRT dr. Hendronoto. Ia meninggal pada Rabu pagi pukul 05.00 WIB. 3 September 2003 di rumah sekaligus galerinya, J1. Solo Km 9,8 Desa Maguwoharjo, Depok, Kabupaten Sleman, DIY dalam usia 78 tahun. Jenazahnya dimakamkan di Makam Seniman ini. Sapto Hoedojo meninggalkan satu istri, yaitu Yani Sapto Hoedojo serta sembilan orang anak. ${ }^{12}$

Kompleks pemakaman seniman yang didirikan oleh Sapto Hoedojo ini memang cukup kontroversial. Pada suatu saat, ia memiliki suatu ide yang dianggap konyol oleh para koleganya. Ide tersebut adalah keinginan-nya untuk membangun sebuah kompleks pemakaman yang dikhususkan untuk para seniman. Dia beranggapan bahwa seniman layak dihargai karena karya-karyanya. Oleh karena itu, pembangunan sebuah kompleks makam seniman bisa menjadi cara bagi orang-orang untuk mengenang karya-karya para seniman tersebut. $^{13}$

Mengenai gagasan aneh yang dilontarkan oleh Sapto Hoedojo tersebut, terdapat pihak yang menolak, tetapi juga ada yang menyetujui. Salah satu seniman yang menyetujui gagasannya ini adalah Affandi, seorang pelukis terkenal sekaligus mantan mertua Sapto Hoedojo, dan juga telah mendaftarkan diri menjadi calon penghuni kompleks makam yang hendak dibangunnya itu, meskipun setelah meninggal ia tidak jadi dimakamkan di pemakaman tersebut, sebab istrinya meminta

${ }^{12}$ Lina, "Sapto Hudoyo, Dari Kuli Jadi Pelukis Kaliber Internasional," Trenggalek Jelita, diakses 20 Maret 2018, http://www.trenggalekjelita.web.id/2010/08/sapto-hudoyo-dari-kuli-jadi-pelukis.html.

13 Gudeg Net, "Makam Giri Sapto Yogyakarta," Gudeg Net, diakses 18 Januari 2018, https://gudeg.net/direktori/1836/makam-giri-sapto-yogyakarta.html. almarhum suaminya itu dimakamkan di museum Affandi Yogyakarta. ${ }^{14}$

Gagasan membangun kompleks pemakaman tersebut akhirnya disetujui oleh Bupati Bantul waktu itu, KRT Suryapamo Hadiningrat, dengan memberikan sebidang tanah di perbukitan Wukirsari untuk dijadikan pemakaman tersebut. Pembangunan kompleks pemakaman seniman pun terwujud pada 6 Februari 1988. ${ }^{15}$ Kompleks pemakaman tersebut diresmikan dengan nama "Makam Seniman Pengharum Bangsa" oleh Sri Sultan Hamengku Buwono IX, tetapi Sapto Hoedojo kemudian mengganti nama pemakaman tersebut dengan "Taman Makam Seniman dan Budayawan Giri Sapto" 16 dan nama inilah yang dipakai oleh kompleks makam ini hingga sekarang ini. $^{17}$

Meskipun pendirinya, Sapto Hoedojo, meninggal pada tahun 2003, akan tetapi peringatan setahun meninggalnya (haul) acapkali masih diperingati. Lazimnya, tiap kali diadakan haul, para seniman berkumpul di sini seraya mengadakan suatu aktifitas tertentu. Dalam peringatan haul tahun 2013 misalnya, 88 pelukis sepanjang hari ahad melakukan aksi melukis bersama di bawah kerindangan pepohonan yang menaungi perbukitan Giri Sapto tersebut. Para pelukis yang terlibat di antaranya, Joko Pekik, GM Sidharta, Nasirun, Godod Suteja, Sekarlangit Sapto Hoedojo, dan Mahyar. $^{18}$

\section{b. Wujud Makam Seniman}

Lokasi Makam Seniman berada di dekat Makam Raja-Raja Mataram, sekitar 250 meter

${ }^{14}$ Gudeg Net, "Makam Giri Sapto Yogyakarta."

15 Tanggal pembangunan kompleks makam ini dapat dilihat pada tulisan atas bagian pendopo, yang juga menjadi cungkup makam pendiri kompleks pemakaman ini, yakni Sapto Hoedojo. Pendopo ini bertegel putih dan ditopang oleh delapan tiang berwarna putih.

${ }^{16}$ Gudeg Net, "Makam Giri Sapto Yogyakarta."

17 Pada saat masuk kompleks pemakaman, pengunjung akan disuguhi dengan tulisan yang terukir di papan pengenalan yang dibuat dengan semen bertuliskan "Taman Makam Seniman dan Budayawan Giri Sapto Imogiri Yogyakarta.”

${ }^{18}$ Kegiatan ini terjadi pada 10 Maret 2013, disadur dari www.rrijogja.co.id diakses tanggal 27 Mei 2013. 
saja. Tepatnya, makam ini berada di bukit Gajah, desa Girirejo, kecamatan Imogiri, kabupaten Bantul, Daerah Istimewa Yogyakarta dan memiliki luas sekitar lima hektar. Keberadaan Makam Seniman yang berdekatan dengan Makam Raja-Raja Mataram ini pada dasarnya diusahakan oleh Kepala Desa, R. Harsoyo, yang diambilkan dari Tanah Kas Desa (TKD). ${ }^{19}$ Kebanyakan pengunjung Makam Seniman ini sendiri ingin menikmati pemandangan dan suasana saja, berbeda dengan dengan Makam Raja-Raja Mataram yang memang berniat untuk berziarah. ${ }^{20}$

Memang pendirian makam ini dimaksudkan untuk ziarah dan mengenang nama-nama para seniman karena mereka tidak ubahnya sebagai pahlawan, namun pada prakteknya ziarah hanya dilakukan oleh pihak keluarga dari para seniman itu sendiri. Para pengunjung di luar keluarga lebih banyak menghabiskan waktu di areal makam untuk menikmati daerah Imogiri dari ketinggian. Maklum saja, karena desain areal makam yang menyerupai taman memungkinkan para pengunjung untuk bersantai dan bercengkrama. Pemakaman ini sendiri ramai pada hari ahad dan hari lebaran layaknya tempat wisata pada umumnya. ${ }^{21}$

Dari sisi lokasi, penempatan Makam Seniman yang berada di wilayah perbukitan

${ }^{19}$ Atas jasa inilah, R. Harsoyo bisa dimakamkan di Makam Seniman ini, meskipun ia bukan seorang seniman. Begitu pula puteranya yang juga menjadi Kepala Desa, Bayu Bintoro, dimakamkan di makam ini walaupun ia juga bukan seniman.

${ }^{20}$ Jamzari (juru kunci makam), wawancara oleh Benny Afwadzi, kompleks Taman Makam Seniman dan Budayawan Giri Sapto Imogiri Yogyakarta, tanggal 10 Januari 2018, dan diramu dengan penuturan beberapa warga sekitar dan pengunjung makam.

${ }^{21}$ Jamzari (juru kunci makam), wawancara oleh Benny Afwadzi, kompleks Taman Makam Seniman dan Budayawan Giri Sapto Imogiri Yogyakarta, tanggal 5 Mei 2013. Namun, pada saat sekarang ini, kondisi makam tidak seramai dahulu meskipun pada hari ahad dan terlihat kondisi makam sudah agak tidak terawat. Makam ini sendiri hendak diambil alih oleh Dinas Kebudayaan, sebab makam dengan tipe seperti ini tidak ada di belahan bumi lainnya dan termasuk salah satu ritus kebudayaan di Yogyakarta. Jamzari (juru kunci makam), wawancara oleh Benny Afwadzi, kompleks Taman Makam Seniman dan Budayawan Giri Sapto Imogiri Yogyakarta, tanggal 10 Januari 2018. sebenarnya hampir serupa dengan makammakam khas Jawa yang lazimnya diperuntukkan untuk para raja, termasuk pula Makam Raja-Raja Mataram Imogiri di dekatnya yang juga berada di perbukitan. Bagi masyarakat Jawa, gunung atau bukit menjadi simbol kedudukan yang tinggi sekaligus sebagai upaya mendekatkan diri pada Tuhan. ${ }^{22}$ Pendiri makam ini sendiri, Sapto Hoedojo, masih merupakan keturunan bangsawan keraton dan banyak pula penghuni kompleks pemakaman yang masih berdarah keraton. ${ }^{23}$

Sebagai sebuah "karya seni", kompleks makam ini pun cukup unik. Desain kompleks makam mengikuti bentuk bukit, berjenjang, dan dilengkapi susunan tangga beton. Ketika memasuki pelataran makam ini, para pengunjung akan disambut oleh deretan tangga dengan gerbang berbentuk setengah lingkaran yang berbentuk seperti pelangi seperti tampak dalam gambar 1. Gerbang ini tampak monumental karena ukurannya lumayan besar dengan diameter lebih dari 10 meter. Di tengah-tengahnya terdapat patung Sapto Hoedojo, pendiri dan pemrakarsa taman makam ini, yang diresmikan tepat pada hari pahlawan, yakni tanggal 10 November 2015.

Pada bagian utara pelataran makam terdapat cungkup makam Sapto Hoedojo seperti dalam gambar 2, berbentuk pendopo yang meninggal pada 3 September 2003. Cungkup ini ditopang oleh delapan tiang sebagai penyangga dan bertuliskan "Bangsal Asih, 62-1988, Sumbangsih Ibu Yani Sapto Hoedojo." Unsur warna putih sangat mendo-

\footnotetext{
${ }^{22}$ Muhammar Khamdevi, "Kajian Pola Permukiman Khas Kampung Lengkong Ulama, Serpong, Banten," DIMENSI (Jurnal Teknik Arsitektur) 39, no. 1 (28 September 2012), https://doi.org/10.9744/dimensi.39.1.31-36.

${ }^{23}$ Salah seorang pengunjung, Rini, memberikan informasi bahwa Makam Raja-Raja Mataram merupakan makam dari pada raja, sedangkan Makam Seniman adalah makam keluarga keraton. Setelah ditelusuri penulis, memang banyak penguni makam ini yang masih mempunyai hubungan darah dengan keraton, meskipun ciri khas penghuni makam adalah seniman dan budayawan. Rini (pengunjung makam), wawancara oleh Benny Afwadzi, kompleks Taman Makam Seniman dan Budayawan Giri Sapto Imogiri Yogyakarta, tanggal 12 Januari 2018
} 
minasi cungkup pendiri makam ini. Sebagai penanda makam Sapto Hoedojo sendiri, terdapat nisan berwarna hitam yang bertuliskan nama, tanggal lahir, dan wafatnya serta adanya beberapa batu kecil yang diletakkan mengelilingi makam dan tiga batu cukup besar yang dijajar sedemikian rupa di utara nisan.

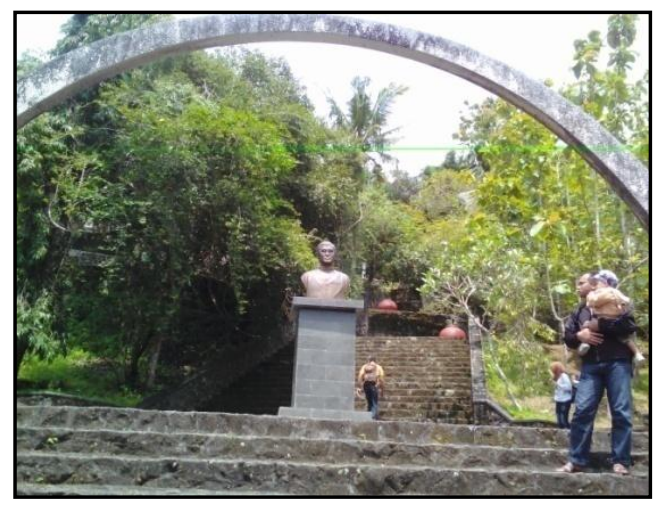

Gambar 1 Gerbang makam Giri Sapto

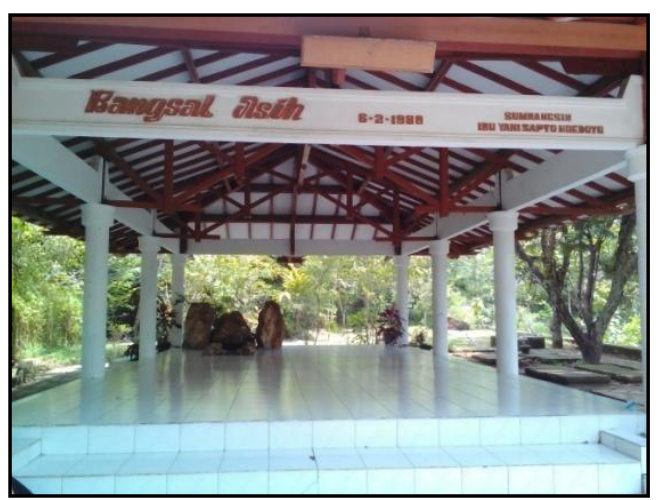

Gambar 2 Cungkup Makam Sapto Hoedojo

Setelah melalui beberapa puluh anak tangga, para pengunjung akan menemukan deretan makam para seniman. Salah satunya adalah maestro lukis Indonesia, H. Widayat, seniman yang mendirikan museum Widayat di daerah Mungkid, Magelang, yang meninggal pada 22 Juni 2002. Selain pelukis, ada pula makam seniman tari terkemuka dari Yogyakarta, yaitu KRT. Sasmintadipura yang meninggal pada 26 Februari 1996. Romo Sas, begitu panggilan akrabnya, dikenal sebagai етри tari gaya Yogyakarta. Di samping menari dan menjadi koreografer tari, ia juga mendirikan Yayasan Pamulangan Beksa Sasminta Mardawa Yogyakarta yang bergerak di bidang kesenian, khususnya tari gaya Yogyakarta.
Tidak hanya seniman lukis dan tari, Makam Seniman juga menjadi peristirahatan terakhir dua komponis terkemuka Indonesia. Mereka adalah Kusbini (gambar 3) dan Liberty Manik (gambar 4).

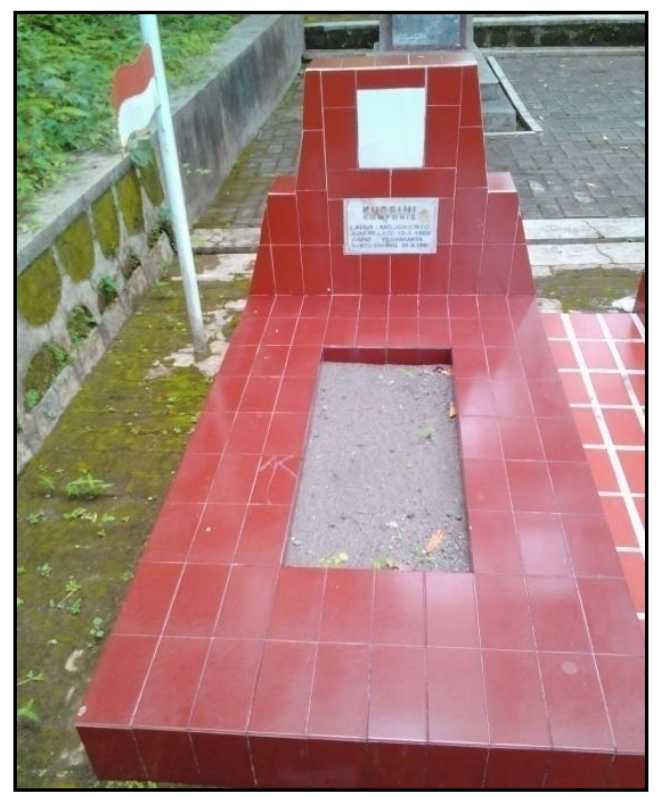

Gambar 3 Makam Kusbini

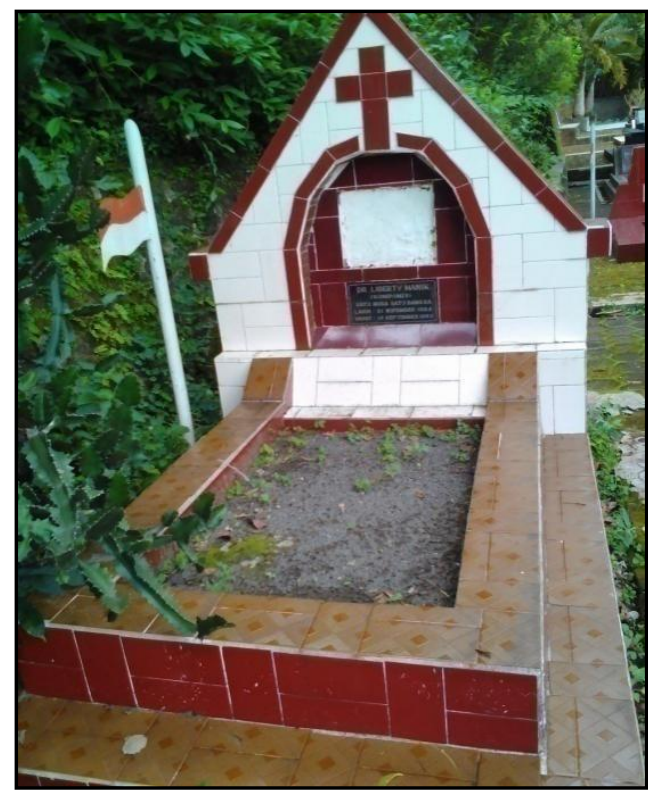

Gambar 4 Makam Liberty Manik

Kusbini adalah komponis yang menciptakan lagu Bagimu Negeri, lagu bernuansa patriotisme yang kerap didengungkan setiap bulan Agustus maupun pada setiap ajang perlombaan yang mengatasnamakan negara. Sementara itu, Dr. Liberty Manik merupakan pencipta lagu Satu Nusa Satu Bangsa yang juga merupakan salah satu lagu kebangsaan 
Indonesia. Kusbini wafat pada 30 Maret 1991, sedangkan Liberty Manik meninggal dua tahun kemudian, yaitu pada 16 September 1993. Karena jasanya pada negara, dua komponis ini memperoleh gelar sebagai Pahlawan Nasional.

Bentuk dari makam Kusbini, komponis yang dinobatkan sebagai pahlawan nasional ini dilapisi keramik berwarna merah dengan pajangan foto almarhum yang dilukis pada media keramik berlatar abstrak di dinding nisan yang mempunyai tinggi sekitar 1 meter. Sementara arsitektur pada makam komponis L. Manik, makam tersebut berhiaskan dinding nisan dilapisi keramik yang mempunyai tinggi sekitar $1 / 2$ meter. Namun, pada makam ini terlihat lebih detail dalam kombinasi warna dan penyusunan dinding yang mempunyai rongga ke dalam bertuliskan identitas almarhum. Di atas rongga terdapat keramik yang bergambarkan salib. Kesan sebagai pahlawan kental dalam kedua arsitektur makam, sebab terdapat sebuah bendera merah putih yang setia menyandingi makam.

Makam seniman merupakan makam dengan ciri khas eksklusivitas profesi tertentu, yang dalam hal ini adalah seniman dan budayawan. Keahlian penghuni makam pun beragam, mulai dari pelukis, pematung, pemusik, hingga artis sinetron. Hampir semuanya dari mereka adalah seniman dan budayawan sesuai tujuan didirikannya makam ini, akan tetapi kemudian ada beberapa orang non seniman dan budayawan juga ikut dimakamkan di sini karena sebab-sebab khusus. Secara lebih jelasnya, para seniman dan budayawan yang dimakamkan di makam ini sampai tanggal 12 Januari 2018 (waktu penelitian ini dilakukan) berjumlah 55 orang yang mayoritas merupakan seniman asal Yogyakarta (lebih lengkapnya lihat lampiran mengenai penghuni makam). ${ }^{24}$

Menurut penuturan Hasan M. Ambary, tipologi makam di Indonesia terdiri atas tiga bentuk, yaitu makam yang berjirat (berkijing), makam tidak berjirat, dan makam yang berjirat

\footnotetext{
${ }^{24}$ Dokumen mengenai ini diperoleh dari juru kunci makam, Jamzari, tanggal 10 Januari 2018 dan disempurnakan oleh penulis.
}

penuh. ${ }^{25}$ Di makam seniman sendiri, kebanyakan makam menggunakan jirat dan bahkan berjirat penuh. Makam yang masih belum berjirat terdapat di areal makam sebelah selatan atau dari gerbang utama ke arah kiri, yang memiliki pintu gerbang khusus. Ketika diamati, makam-makam yang terdapat di areal ini tergolong masih baru dan arealnya masih cukup luas, sehingga dimungkinkan memang belum dijirat. Contoh penguni di areal makam ini seperti Ki Ledjar Soebroto, seorang Dalang Wayang Kancil yang cukup terkenal.

\section{Unsur Seni dalam Makam Seniman}

Di kompleks Makam Seniman, arsitektur makam dibuat dengan bentuk yang sangat unik, yakni dengan menggabungkan pemakaman yang mempunyai karakter ukhrawi dengan seni yang biasanya dipandang sebagai bentuk duniawi. Hasilnya bisa dilihat langsung di pemakaman ini dengan munculnya nisan-nisan dengan arsitektur yang sangat beragam dan memikat. Kuburan yang biasanya identik dengan sakralitas dan keseraman seakan luntur oleh wujudnya yang berbalut seni. Dalam bahasa Jamzari, Juru Kunci makam ini dikatakan dengan "makam tapi tidak (ber)bentuk makam." 26

Fenomena di atas berimplikasi pada santainya pengunjung yang berada di Makam Seniman. Berdasarkan keterangan beberapa pengunjung yang ditemui penulis, mereka tidak merasa takut saat berada di kompleks makam ini. Bahkan dengan unsur seni yang ada dalamnya dan sebagai kumpulan makammakam seniman dan budayawan, menjadikan nilai edukasi tersendiri. Rini, salah seorang pengunjung yang terlihat membawa serta anaknya mengaku seringkali datang ke makam ini. Ia menyatakan bahwa Taman Makam Seniman dan Budayawan Giri Sapto merupakan makam yang bagus sekaligus bisa sebagai sarana untuk memberikan pengajaran pada

\footnotetext{
${ }^{25}$ Effie Latifundia, "Jejak Budaya pada Nisan Kuno Islam di Kuningan”, 39.

${ }^{26}$ Jamzari (juru kunci makam), wawancara oleh Benny Afwadzi, kompleks Taman Makam Seniman dan Budayawan Giri Sapto Imogiri Yogyakarta, tanggal 10 Januari 2018.
} 
anak terkait kesenian di Nusantara dan tokohtokohnya. $^{27}$

Salah satu nisan yang terlihat menarik dan berbalut seni adalah nisan yang terdapat pahatan alat musik jenis gitar seperti pada gambar 5, yang menyimbolkan bidang seni yang digeluti almarhum selama hidup. Ia adalah R. Sudarmadji, Ketua Orkestra RRI Semarang yang wafat pada 17 Februari 1990. Sudarmadji merupakan penghuni awal makam seniman ini pada 19 Februari 1990. Selain itu, terdapat pula makam musisi dengan pahatan peri yang sedang memainkan biolanya seperti dalam gambar 6, yang merupakan makam dari Karnadji Kristanto dengan nama Tionghoa Than Thiam Kwie. Ia merupakan seorang Vionis (pemain biola) asal Yogyakarta yang wafat pada 6 Juni 1992 di kota kelahirannya. Ia dimakamkan di Makam Seniman ini pada 7 Juni 1992.

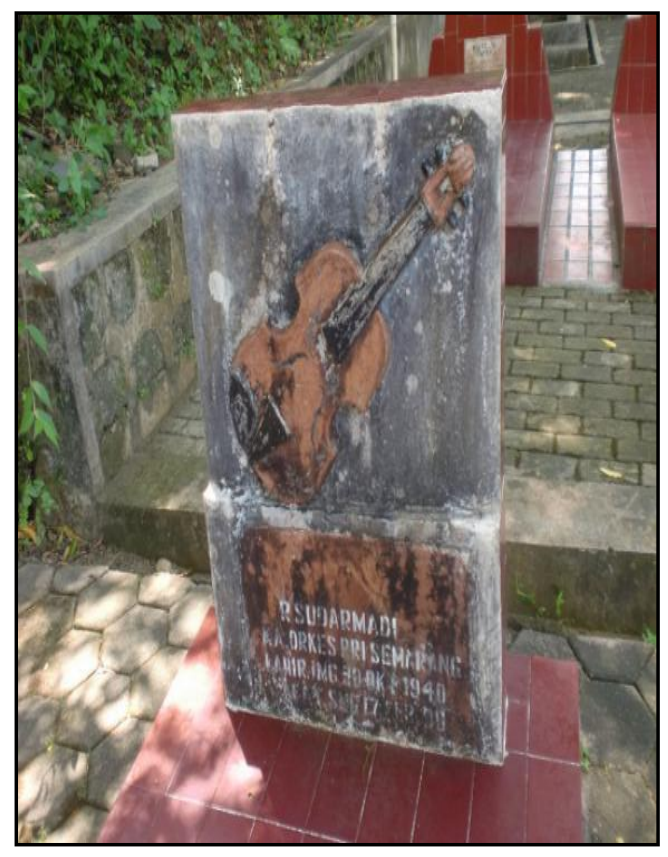

Gambar 5 Nisan Ketua Orkes Sudarmadji

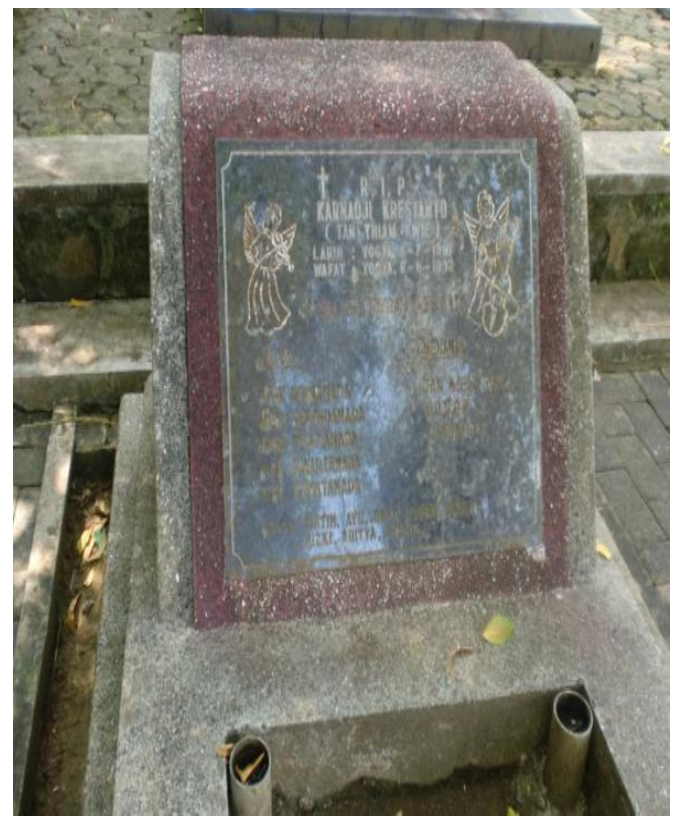

Gambar 6 Nisan Vionis Karnadji Kristanto

Di pemakaman ini, dipajang sebuah puisi dalam sebuah nisan hasil karya Kirdjomuljo, seorang sastrawan yang dimakamkan di sini juga, yang wafat pada 20 Januari 2000. Puisi tersebut berjudul Puisi Rumah Bambu (gambar 7) dan dipasang oleh keluarga almarhum. Hal ini memberikan kultur seni yang cukup menyeruak di kompleks makam ini, di mana hasil karya almarhum bisa dipasang sebagai penanda keberhasilannya dan bisa dinikmati oleh pengunjung makam. Berikut redaksi syairnya:

\author{
Puisi Rumah Bambu \\ Disini aku temukan kau \\ Disini aku temukan daku \\ Disini aku temukan kau \\ Tiada lagi ku sendiri \\ Pandanglah daku \\ Pandanglah daku \\ Aku bicara dengan jiwaku \\ Sampaikan hasratku padamu \\ Disini aku temukan kau \\ Tiada lagi ku sendiri
}

27 Rini (pengunjung makam), wawancara oleh Benny Afwadzi, kompleks Taman Makam Seniman dan Budayawan Giri Sapto Imogiri Yogyakarta, tanggal 12 Januari 2018. 


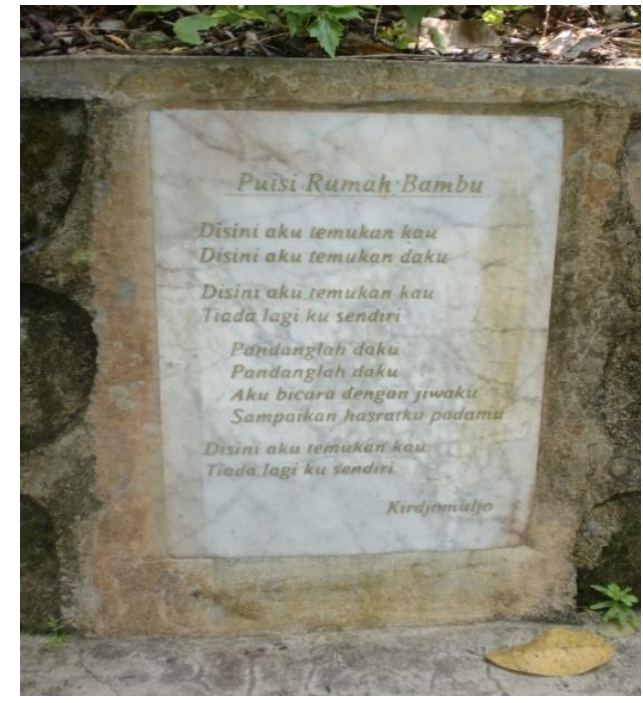

Gambar 7 Puisi Rumah Bambu

Sesuai dengan namanya, unsur seni sangat ditampakkan dalam Makam Seniman dan tidak terlepas dari fenomena-fenomena yang cukup unik. Misalnya saja, pada Maret 2014, tatkala Alexia Maria Endang Nrangwesti, seorang penari perempuan yang cukup terkenal meninggal dan dimakamkan di Makam Seniman, diiringi dengan fenomena yang tidak biasa, yakni bergabungnya seni pertunjukan dalam sebuah pemakaman. Ketika jenazah datang ke makam ini, ia disambut dengan tabuhan musik gamelan lengkap dengan penarinya yang mengiringi jenazah sampai ke liang lahat. ${ }^{28}$ Sal Murgiyanto, penari yang juga merupakan suami A. M. Endang Ngrawesti, menceritakan kronologi kisah tersebut sebagai berikut:

Ketika bertemu mas Sunardi, Kepala Sekolah SMKI di mana Endang pernah belajar menari semasa remaja, saya meminta sekiranya mas Nardi dapat mengumpulkan sekelompok siswa untuk menyanyikannya nanti dalam upacara pemakaman Endang; sebagai ungkapan rasa duka saya yang mendalam dan selamat jalan kepada isteri yang sangat saya cintai, mengantarkannya kembali ke rumah Bapa. Beberapa hari kemudian, ketika mas Nardi

${ }^{28}$ Jamzari (juru kunci makam), wawancara oleh Benny Afwadzi, kompleks Taman Makam Seniman dan Budayawan Giri Sapto Imogiri Yogyakarta, tanggal 10 Januari 2018. menjenguk ke Panti Rapih, saya bertanya, "Mungkinkah koor macapat itu diiringi dengan gamelan?" Mas Nardi menyanggupinya. Tetapi nampaknya gagasan yang tidak biasa itu belum juga mau berhenti. Ketika saya bertemu ibu Sasmintamurti, teman kuliah Endang semasa di ASTI, saya menunjuk-kan puisi Jawa yang saya buat sambil memberanikan diri memohon apakah beliau bersedia menyusun sebuah tarian pendek untuk mengantar Endang ke peristirahatan abadi. Membaca teks Mijil saya, mbak Tiyah (begitu saya biasa memanggilnya di masa kuliah), sambil berurai air mata beliau mengiyakan. ${ }^{29}$

Ia melanjutkan ceritanya:

Segera bu Tiyah mengumpulkan empat penari putri senior-Tutiek Winarti, Heny Winahyuningsih, Retno Nooryastuti, dan Retnaningsih - untuk berlatih marathon di pendapa Pujakusuman dan di ruang kelas SMKI. Ketika pada tanggal 31 Maret 2014 ibu Tiyah melakukan "gladi resik" di halaman Makam Seniman-Budayawan "Girisapto" di Imogiri, Endang dipanggil menghadap Bapa. Keesokan harinya, Srimpi Wiwoho Girisapto "dipertunjukkan" di halaman Gerbang kedua, sebagai bagian upacara mengantar perjalanan isteri tercinta kembali ke rumah Bapa. Martinus Miroto, yang dalam busana tradisi Jawa menjadi cucuking lampah berbisik kepada saya, "Mas Sal, ini untuk yang pertama kali upacara pemakaman disertai pertunjukan tari." Saya membentak lirih, "Ini bukan pertunjukan tetapi bagian dari upacara pemakaman! ${ }^{30}$

Fenomena unik lainnya adalah makam "nyeleneh" di sebelah barat makam pendiri makam ini seperti tampak dalam gambar 8. Di tempat tersebut terdapat makam seekor ayam yang bernama Philip Von Sapto Hoedojo,

${ }^{29}$ Sal Murgiyanto, "Tradisi dan Perubahan: Tidak ada Jalan Pintas untuk Hasil yang Berkualitas, Menyimak Perkembangan Tari Tradisi di Indonesia," in Prosiding Seminar Nasional Seni Pertunjukan dan Pendidikan Seni (Semarang, 2016), 25.

${ }^{30}$ Sal Murgiyanto, "Tradisi dan Perubahan: Tidak ada Jalan Pintas untuk Hasil yang Berkualitas.” 
yang diberikan bentuk kuburan dan nisan layaknya manusia pada umumnya. Sesuai dengan yang tertera di nisan, ayam ini berasal dari Filipina, yang lahir pada 25 Desember 1997 dan mati pada 5 April 2006 di Yogyakarta. Penempatan dan adanya bentuk makam seperti ini yang tidak ubahnya seperti manusia dikarenakan ayam tersebut merupakan ayam kesayangan Sapto Hoedojo semasa menderita penyakit stroke.

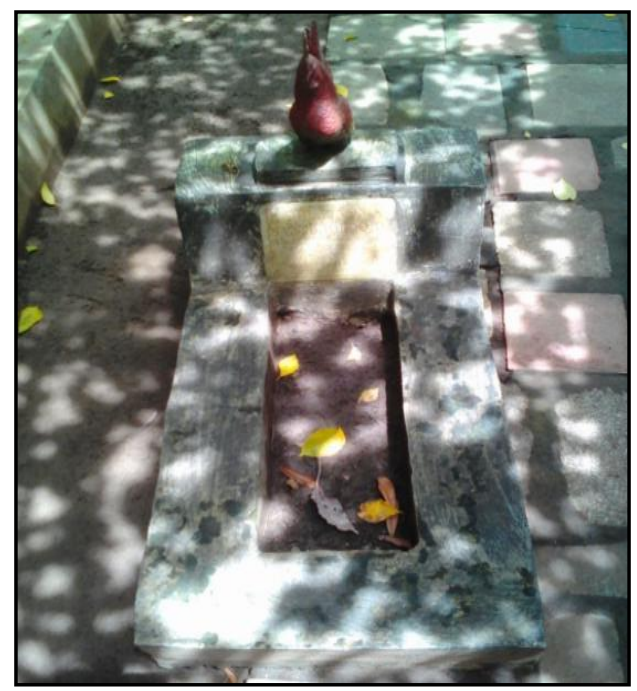

Gambar 8

Makam Philip Von Sapto Hoedojo

\section{Perkembangan Identitas Pemakaman dalam Fenomena Makam Seniman}

Memang diakui bahwa kebudayaan sangat kompleks, sedangkan pengetahuan mengenai kebudayaan juga terus mengalami perkembangan. Oleh karenanya, muncul berbagai pengertian mengenai kebudayaan agar terdapat batasan yang jelas. Secara umum, kebudayaan biasa dimaknai sebagai hasil cipta, rasa, dan karsa manusia. E. B. Tylor (w. 1917), seorang antropolog pencetus istilah animisme, mendefinisikan kebudayaan sebagai "keseluruhan yang kompleks meliputi pengetahuan, kepercayaan, kesenian, hukum, moral, adat, dan berbagai kemampuan serta kebiasaan yang diperoleh manusia sebagai anggota masyarakat." $" 31$

${ }^{31}$ Hari Poerwanto, Kebudayaan dan Lingkungan dalam Perspektif Antropologi (Yogyakarta: Pustaka Pelajar, 2010), 52.
Definisi di atas begitu meluas dalam segala sendi kehidupan manusia, sebab memang kebudayaan sangat sulit diberikan batasan yang pasti, bahkan agama (religi) pun dalam antropologi dimasukkan dalam sistem kebudayaan. Definisi kebudayaan yang agaknya membantu kajian terhadap Makam Seniman adalah definisi yang diutarakan oleh A. L. Kroeber (w. 1960) dan C. Kluckhohn (w. 1960), yang menyebutkan kebudayaan merupakan keseluruhan pola-pola tingkah laku dan pola-pola bertingkah laku, baik yang eksplisit maupun implisit, yang diperoleh dan diturunkan melalui media simbol, yang pada akhirnya bisa menciptakan sesuatu yang khas dari kelompok-kelompok manusia, termasuk perwujudannya dalam benda-benda materi. ${ }^{32}$

Perwujudan makam seniman yang mempunyai ciri khas unsur artistik merupakan sebuah kebudayaan yang dihasilkan dari pola tingkah laku dan pola bertingkah laku dari para seniman yang memiliki kreasi yang lebih dibandingkan masyarakat pada umumnya. Pola tersebut kemudian dimanifestasikan dalam simbol-simbol tertentu yang sarat dengan nuansa seni, baik dalam arsitektur makam secara keseluruhan, nisan makam, hiasan makam, maupun prosesi pemakaman. Seniman bukan orang yang mempunyai pola pikir layaknya orang kebanyakan. Mereka mempunyai gaya pemikiran yang khas dan out of the box (keluar dari pemikiran mayoritas). Gaya berpikir seperti inilah yang mengakibatkan sebagian dari mereka di kompleks makam seniman ini mempunyai simbol-simbol yang unik, seperti nisan yang bergambarkan gitar, puisi hasil karya almarhum yang dipajang, dan pemakaman yang diiringi dengan gamelan dan tarian, bahkan ayam yang dibuatkan makam layaknya manusia pada umumnya.

Sesuatu yang khas dari para seniman itulah yang membentuk kebudayaan yang melekat pada Makam Seniman dan menjadi identitas pembeda dengan kompleks-kompleks makam lainnya. Taman Makam Seniman dan Budayawan Giri Sapto merupakan tipe kompleks makam yang diakibatkan adanya kebudayaan

${ }^{32}$ Hari Poerwanto, Kebudayaan dan Lingkungan dalam Perspektif Antropologi., 
seni yang mengakar kuat dalam kehidupan manusia. Pendiri makam ini, Sapto Hoedojo, merupakan seorang seniman di bidang lukisan. Sebagai seorang yang bergelut dalam dunia seni menjadikan dirinya mempunyai ide yang tidak biasa, yakni membuat kompleks makam yang hanya diperuntukkan bagi seniman saja, dan akhirnya terealisasi dalam wujud Makam Seniman.

Kesenian dalam kajian antropologi dan sosiologi termasuk dalam kategori pranata, yaitu sistem yang menjadi sarana yang memungkinkan masyarakat untuk berinteraksi dengan pola-pola yang resmi. Salah satu klasifikasi pranata adalah aesthetic and recreational institutions, yakni pranata yang berfungsi memenuhi keperluan manusia untuk menghayatkan rasa keindahannya dan untuk rekreasi, seperti seni rupa, seni suara, seni gerak, seni drama, kesusastraan, olah raga, dan lain sebagainya. ${ }^{33}$ Pranata kesenian berisi sistem aktivitas yang melibatkan unsur-unsur emosi estetika, konsep-konsep seni, benda-benda peralatan fisik, dan seniman sebagai pelakupelaku kesenian. Unsur-unsur dalam pranata seni tersebut saling berkaitan satu dengan lainnya. ${ }^{34}$

Kebudayaan pasti mengalami perkembangan dan pergeseran sesuai dengan kebutuhan dan tujuan dari manusia itu sendiri. Dalam memahami perkembangan kebudayaan tersebut, para ahli antropologi memandang bahwa kebudayaan hanyalah sebuah konsep untuk suatu konstruksi. Melalui pandangan ini, kebudayaan bisa digunakan untuk menjelaskan dan menggambarkan tingkah laku dan yang dihasilkan oleh manusia. ${ }^{35}$ R. Linton (w. 1953) menyatakan bahwa kebudayaan hanya merupakan wujud dari pikiran seseorang yang pada akhirnya menjadi suatu kepribadian jika ia berinteraksi dengan individu lainnya dalam sebuah komunitas masyarakat. Semua pola

33 Koentjaraningrat, Pengantar Ilmu Antropologi (Jakarta: Rineka Cipta, 2002), 163.

${ }^{34}$ Yadi Mulyadi dan Muhammad Nur, "Ragam Hias pada Makam di Komplek Mesjid Makam Turikale di Maros Sulawesi Selatan.," Kalpataru 26, no. 1 (September 2017): 27-36, doi:10.24832/kpt.v26i1.222.

${ }^{35}$ Hari Poerwanto, Kebudayaan dan Lingkungan dalam Perspektif Antropologi, 90. kebudayaan dapat dipahami dari tingkah polah individu, karena perkembangan kebudayaan lebih dipengaruhi oleh pengalaman-pengalaman individu masyarakat. ${ }^{36}$

Sebagai sebuah kebudayaan, eksistensi makam mengalami perkembangan dari satu masa ke masa selanjutnya yang dipengaruhi oleh pengalaman individu-individu dalam masyarakat. Sampai saat ini, identitas makam menemukan beberapa variannya sendiri-sendiri. Ia berkembang sesuai dengan kebudayaan yang dihasilkan oleh manusia itu sendiri dalam lingkungannya. Bagaimana tingkah polah manusia dalam suatu masa menentukan wujud identitas makam yang ada. Fenomena seperti ini merupakan hal yang lumrah mengingat hasil pikiran dan perilaku manusia memang sangat dipengaruhi oleh kondisi di mana ia hidup, sebab tidak mungkin ada manusia yang hidup dalam ruang hampa.

Sebagai contoh perkembangan identitas makam, sebuah masa yang sangat mengunggulkan doktrin-doktrin keagamaan nantinya akan mengantarkan pada tipe kompleks makam yang bercirikan agama. Agama tertentu, misalnya Islam atau Kristen menjadi pemisah yang memperbolehkan atau tidak memperbolehkan seseorang dimakamkan di kompleks tersebut. Biasanya orang atau juga bahkan keluarga almarhum pun tidak berkenan bila dikebumikan di kompleks makam yang tidak seagama dengannya. Terdapat idealitas sebagai penganut agama yang taat untuk tidak dimakamkan berdampingan dengan orang yang berbeda keyakinan.

Berkebalikan dengan kompleks makam agama, terdapat pula kompleks makam yang tidak mengenal ekskluvitas agama tertentu, yang acapkali disebut oleh masyarakat sebagai "Makam Pancasila." Adanya tipe kompleks semacam ini terjadi akibat adanya pengunggulan nilai nasionalisme sebagai suatu bangsa yang tidak mengenal batas-batas tertentu dan menggantikan eksklusivitas agama. Pancasila dipandang sebagai pemersatu antar suku bangsa, agama, dan bahasa yang berbeda-beda di Indonesia. Oleh sebab itu, di makam

\footnotetext{
${ }^{36}$ Hari Poerwanto, Kebudayaan dan Lingkungan dalam Perspektif Antropologi, 90.
} 
Pancasila, semua agama dapat dikebumikan tanpa terkecuali dan bisa berdampingan satu dengan lainnya.

Di bumi Nusantara juga muncul makam pahlawan yang dikhususkan pada pejuang bangsa Indonesia. Dalam konteks ini, kebudayaan mengenai kepahlawanan muncul dan berkembang sehingga mengantarkan pada terwujudnya tipe makam seperti ini. Indonesia merupakan negara terjajah, terutama oleh Belanda dan akhirnya memunculkan sosok-sosok pahlawan. Pahlawan sendiri adalah orang yang meninggal dalam memperjuangkan kemerdekaan Indonesia atau orang yang membantu perjuangan dalam berbagai kapasitanya. Oleh karena itu, mereka harus diberikan penghargaan, yang salah satunya adalah berupa makam khusus yang biasa disebut sebagai Taman Makam Pahlawan (TMP). Hampir di setiap daerah di Indonesia terdapat Taman Makam Pahlawannya, misalnya saja Taman Makam Pahlawan Kalibata di Jakarta, Taman Makam Pahlawan Kusumanegara di Yogyakarta, Taman Makam Pahlawan Giritunggal di Semarang, dan Taman Makam Pahlawan Cikutra di Bandung.

Sebagai wilayah yang dahulunya terdiri atas kerajaan-kerajaan pun, Indonesia memiliki kompleks makam yang hanya diperuntukkan untuk raja-raja dan keluarga kerajaan saja. Biasanya berada pada tempat yang agak tinggi atau perbukitan. Contoh tipe kompleks makam seperti ini yang paling dekat dengan Makam Seniman adalah Makam Raja-Raja Mataram Islam Imogiri. Meskipun orang yang diperbolehkan untuk dimakamkan di sini hanya yang beragama Islam saja, ${ }^{37}$ akan tetapi aspek yang ditonjolkan adalah karakter sebagai kompleks makam raja, sehingga unggahungguh laksana rakyat yang hendak menemui rajanya pun sangat diperhatikan di kompleks area makam ini.

Mengikuti pola makam kerajaan, di Indonesia pula terbentuk makam khusus keluarga

${ }^{37}$ Slamet Abdurrahman (kaum masyarakat sekitar Makam Seniman sekaligus juru kunci Makam RajaRaja Imogiri), wawancara oleh Benny Afwadzi, kompleks Makam Raja-Raja Mataram, tanggal 12 Januari 2018. pesantren, yang bisa dikatakan sebagai "kerajaan kecil." Sebagai negara dengan penduduk Muslim terbesar di dunia, Indonesia mempunyai banyak pondok pesantren yang tersebar di berbagai wilayah, utamanya di Jawa. Sebagian di antaranya mempunyai kompleks pemakaman sendiri, yang dikhususkan untuk kalangan keluarganya. Sebut saja misalnya kompleks makam keluarga pesantren Tebuireng di Jombang yang di dalamnya dimakamkan tiga orang tokoh nasional yang berasal dari pesantren Tebuireng, yakni KH. Hasyim Asyari, KH. Wahid Hasyim, dan KH. Abdurrahman Wahid.

Tipologi identitas makam agama, makam Pancasila, makam pahlawan, makam kerajaan, dan makam pesantren merupakan identitas yang boleh dikatakan muncul di era dahulu kala, meskipun masih dilestarikan hingga saat sekarang ini. Secara antropologis, kemunculan identitas kompleks makam yang berbeda tersebut disebabkan kondisi kebudayaan yang berbeda-beda antara satu dengan lainnya. Kebudayaan inilah yang kemudian bisa menjelaskan bagaimana tingkah laku masyarakat kala itu, sebab pada hakikatnya kebudayaan bersumber dari mereka sendiri sebagai subjeknya. Pencetus dan pelaku masingmasing tipe identitas makam pastilah mempunyai wujud kebudayaan yang berlainan dan dunianya sendiri-sendiri. Hal ini disebabkan budaya bersifat dinamis, berubah-ubah dan tidak statis.

Taman Makam Seniman dan Budayawan Giri Sapto adalah hasil karya kebudayaan yang dihasilkan oleh subjek-subjek yang terdapat di makam ini, baik pendiri makam, juru kunci, penguni makam, maupun keluarga almarhum. Jenis identitas makam dengan model seperti ini (Makam Seniman), yakni berpijak pada profesi atau bidang yang ditekuni oleh seseorang tatkala masih hidup boleh jadi menjadi ciri khas kebudayaan pemakaman pada masa modern. Ia dikatakan menjadi bentuk perkembangan identitas makam yang ada di era mutakhir dengan keunikan-keunikan tertentu, sehingga identitas sebuah makam tidak melulu didasarkan atas agama dan stratifikasi tertentu. Makam-makam dengan 
tipologi baru yang muncul sangat dimungkinkan mengacu pada kesesuaian profesi atau bidang kajian yang berkembang di masa kini sebagai manifestasi perkembangan kebudayaan yang terjadi pada diri manusia. Ini tergambarkan jelas dalam fenomena Makam Seniman. Paling tidak dalam fenomena lain, muncul pula makam yang hanya dikhususkan untuk dosen-dosen sebuah universitas tertentu, misalnya saja kompleks makam khusus bagi dosen-dosen Universitas Brawijaya (UB) di Malang, yang memiliki kesesuaian karakteristik (profesi atau bidang kajian) dengan Makam Seniman ini.

Makam Seniman, jika ditilik secara lebih mendalam, sebenarnya memuat berbagai macam agama, yang sampai saat ini terdiri atas tiga agama, yaitu Islam, Kristen, dan Hindu. Masing-masing penganut agama mempunyai karakteristik nisan tertentu yang sebagian juga menunjukkan identitas keagamaannya. Jamzari, juru kunci Makam Seniman, menyatakan bahwa kompleks makam bisa terdiri atas berbagai agama maupun kepercayaan. Agama merupakan urusan personal antara manusia dengan Tuhannya, sehingga tidak berimplikasi pada komposisi makam. Maka, Makam Seniman ini pun terbentuk atas berbagai agama yang berlainan, yang penting almarhum merupakan seorang seniman. ${ }^{38}$

Sebenarnya, pengaitan antara seni dan pemakaman bukanlah sesuatu yang benarbenar baru. Telah banyak makam yang mempunyai nilai estika dan artistik yang tinggi. Misalnya yang paling fenomenal dalam sejarah adalah Taj Mahal di India, yang didirikan oleh Syah Jehan pada tahun 1632 sampai 1648 sebagai monumen peringatan untuk istri ketiganya yang telah meninggal, Mumtaz Mahal. Begitu pula makam Uljaytu (13041316) di Iran, yang dikenal sebagai Taj Mahalnya negara Iran. Ujlaytu sendiri merupakan penguasa keempat dari dinasti Ilkhaniyah. Dalam kompleks makam ini terdapat delapan menara, masing-masing berbentuk silindris

38 Jamzari (juru kunci makam), wawancara oleh Benny Afwadzi, kompleks Taman Makam Seniman dan Budayawan Giri Sapto Imogiri Yogyakarta, tanggal 5 Mei 2013. berdiri pada setiap sudut atas dinding, mengelilingi kubah. Di antara kubah dan puncak dinding samping terdapat pelataran keliling. Bagian luar kubah saat ini masih kelihatan sisa-sisa lapisan keramik berwarna biru dengan pola geometris-intricate dan arabesque. $^{39}$

Di Indonesia sendiri, makam-makam kuno, terutama makam raja dan keluarganya, banyak yang memiliki pahatan-pahatan menarik dan tulisan kaligrafi yang bernuansa artistik. Misalnya saja, kompleks makam kuno masjid Turikale, Maros Sulawesi Selatan yang diperuntukkan untuk keluarga dan keturunan bangsawan Turikale. Nilai artistik yang dibawakan makam ini adalah bercirikan paham representative art dengan menampilkan sulursuluran dan bunga dengan kelopak bunga yang menengadah di bagian jirat. Hal tersebut ditambah dengan keindahan kaligrafi dengan khat tsuluts yang ada di kompleks makam ini. Tidak ditemukan motif hias dan kaligrafi yang meniru atau memanipulasi bentuk makhluk hidup supaya menghindari adanya pengkultusan sosok selain Allah. ${ }^{40}$

Meskipun demikian, kompleks makam kuno berdiri di atas kebudayaan seni pada masanya, yang tentu saja berlainan dengan kebudayaan seni pada masa modern. Realitas itulah yang menyebabkan seni artistik Makam Seniman dengan seni artistik makam-makam kuno pasti tidak akan sealiran, apalagi serupa. Kompleks makam dengan identitas berupa seniman dan budayawan tidak akan ditemukan di belahan bumi lain, selain di Taman Makam Seniman dan Budayawan Giri Sapto Yogyakarta. Yogyakarta memang terkenal menyimpan kebudayaan yang melimpah ruah, salah satunya adalah Makam Seniman yang didirikan oleh Sapto Hoedojo ini. Seni yang pada hakikatnya merupakan bidang yang digeluti manusia tatkala masih hidup, ternyata dapat berjalin kelindan dengan kematian yang lazimnya identik dengan unsur sakralitas. Ia

${ }^{39}$ Judith Kolbas, The Mongols in Iran (London: Routledge, 2013), doi:10.4324/9781315027036.

${ }^{40}$ Mulyadi dan Nur, "Ragam Hias pada Makam di Komplek Mesjid Makam Turikale di Maros Sulawesi Selatan." 
seakan berjalan menembus ruang dan waktu antara kehidupan dan kematian. Dalam pendapat R. Hertz, salah seorang antropolog asal Prancis, disebutkan bahwa mati merupakan peralihan dari kedudukan sosial tertentu kepada kedudukan sosial yang lain, yakni kedudukan sosial di dunia ini menuju kedudukan sosial dalam dunia yang lain. ${ }^{41}$

\section{SIMPULAN}

Taman Makam Seniman dan Budayawan Giri Sapto merupakan kompleks makam yang berbeda dari yang lain. Ia merupakan kompleks makam dengan eksklusivitas profesi tertentu, yakni seniman dan budayawan, yang tidak ditemukan dalam tempat lain. Ia juga sarat dengan unsur-unsur seni, karena didirikan oleh seniman bernama Sapto Hoedojo dan diperuntukkan bagi para seniman untuk mengenang karya-karya mereka, meskipun ada beberapa penghuni makam nonseniman dimakamkan di sini karena sebabsebab tertentu. Beberapa unsur seni yang terlihat kentara dalam kompleks makam ini adalah adanya beberapa nisan dengan bentuk unik yang menyimbolkan bidang kesenian almarhum tatkala masih hidup, hasil karya seni yang dipajang di makam, dan adanya upacara pemakaman yang dibalut dengan kesenian.

Fenomena makam seniman Giri Sapto merupakan sebuah bentuk perkembangan identitas pemakaman pada masa modern yang sarat dengan keunikan-keunikan tertentu. Eksistensinya disebabkan akibat adanya perkembangan kebudayaan manusia, yang dalam konteks Makam Seniman diwujudkan oleh kesenian. Makam Seniman pada hakikatnya memuat perkembangan jati diri sebagai sebuah tempat pemakaman, yang sebelumnya telah muncul makam dengan model identitas agama, Pancasila, pahlawan, kerajaan, dan pesantren. Jenis identitas makam dengan model seperti ini (Makam Seniman), yakni mengikuti profesi atau bidang yang ditekuni oleh seseorang boleh dikatakan menjadi ciri khas kebudayaan pemakaman pada masa modern.

${ }^{41}$ Koentjaraningrat, Sejarah Teori Antropologi I (Jakarta: UI Press, 2014), 71.

\section{DAFTAR PUSTAKA}

Barata. "Peresmian Patung Sapto Hoedojo di Makam Seniman." Tembi News, t.t.

Gudeg Net. "Makam Giri Sapto Yogyakarta." Gudeg Net, t.t.

Handoko, Wuri. "Tradisi Nisan Menhir pada Makam Kuno Raja-raja di Wilayah Kerajaan Hitu." Kapata Arkeologi 10, no. 1 (April 2016): 33-46. doi:10.24832/kapata.v10i1.216.

Khamdevi, Muhammar. "Kajian Pola Permukiman Khas Kampung Lengkong Ulama, Serpong, Banten.” DIMENSI (Jurnal Teknik Arsitektur) 39, no. 1 (September 2012). doi:10.9744/dimensi.39.1.31-36.

Koentjaraningrat. Pengantar Ilmu Antropologi. Jakarta: Rineka Cipta, 2002.

Kolbas, Judith. The Mongols in Iran. London: Routledge, 2013. doi:10.4324/9781315027036.

Latifundia, Effie. "Jejak Budaya pada Nisan Kuno Islam di Kuningan." Al-Turas: Mimbar Sejarah, Sastra, Budaya, dan Agama 21, no. 1 (2015): 30-41.

Lina. "Sapto Hudoyo, Dari Kuli Jadi Pelukis Kaliber Internasional." Trenggalek Jelita, t.t.

Mujib, M Misbahul. "Fenomena Tradisi Ziarah Lokal dalam Masyarakat Jawa: Kontestasi Kesalehan, Identitas Keagamaan dan Komersial." IBDA': Jurnal Kajian Islam dan Budaya 14, no. 2 (Oktober 2016): 204-24. doi:10.24090/ibda.v14i2.673.

Mulyadi, Yadi, dan Muhammad Nur. "Ragam Hias pada Makam di Komplek Mesjid Makam Turikale di Maros Sulawesi Selatan." Kalpataru 26, no. 1 (September 2017): 27-36. doi:10.24832/kpt.v26i1.222.

Murgiyanto, Sal. "Tradisi dan Perubahan: Tidak ada Jalan Pintas untuk Hasil yang Berkualitas, Menyimak Perkembangan Tari Tradisi di Indonesia." Dalam Prosiding Seminar Nasional Seni Pertunjukan dan Pendidikan Seni, 15-31. Semarang, 2016.

Muslim, Abu. "Simbol pada Makam Syekh 
Bil Ma'ruf dan Sosio-Religi Pulau Tangnga Sulawesi Barat." Jurnal Lektur Keagamaan 14, no. 2 (Desember 2016): 257-80. doi:10.31291/jlk.v14i2.501.

Poerwanto, Hari. Kebudayaan dan Lingkungan dalam Perspektif

Antropologi. Yogyakarta: Pustaka Pelajar, 2010.

Puput Tri Hardiyanti, Wahyudi, Nurodin, Unun Achmad Alimin, Zu. "Sinergitas Islam dan Budaya dalam Kearifan Lokal (Studi Kasus Pada Komplek Pemakaman Raja-Raja Imogiri di Desa Panjaitan Imogiri)." EMPIRISMA 26, no. 1 (Juli 2017).

doi:10.30762/empirisma.v26i1.683.

Rokhim, Maliky Nur. "Unsur Religi dalam

Tradisi Nguras Enceh di Makam RajaRaja Imogiri." Universitas Negeri Yogyakarta, 2013.

Saefullah, Asep. "Inskripsi pada Kompleks Makam Raja-raja Mempawah, Kalimantan Barat." Suhuf: Jurnal Pengkajian al-Quran dan Budaya 5, no. 1 (2012): 77-95. doi:10.22548/shf.v5i1.51.

Sarjono. "Motivasi Masyarakat Menghadiri Tradisi Nguras Kong di Makam RajaRaja Mataram Imogiri." UIN Sunan Kalijaga Yogyakarta, 2013.

Syam, Nur. Madzhab-Madzhab Antropologi. Yogyakarta: LKiS, 2009.

Tjandrasasmita, Uka. "Kutipan Ayat-ayat AlQur'an dan Kalimat Sufistik pada Beberapa Batu Nisan Makam Kuno di Indonesia." Suhuf: Jurnal Pengkajian alQuran dan Budaya 2, no. 2 (2009): 24970. doi:10.22548/shf.v2i2.91.

\section{WA WANCARA}

Jamzari (juru kunci makam), wawancara oleh Benny Afwadzi. Kompleks Taman Makam Seniman dan Budayawan Giri Sapto Imogiri Yogyakarta. Tanggal 5 Mei 2013.

Jamzari (juru kunci makam), wawancara oleh Benny Afwadzi. Kompleks Taman Makam Seniman dan Budayawan Giri Sapto Imogiri Yogyakarta. Tanggal 10 Januari 2018.

Rini (pengunjung makam), wawancara oleh Benny Afwadzi. Kompleks Taman Makam Seniman dan Budayawan Giri Sapto Imogiri Yogyakarta. Tanggal 12 Januari 2018.

Slamet Abdurrahman (kaum masyarakat sekitar Makam Seniman sekaligus juru kunci Makam Raja-Raja Imogiri), wawancara oleh Benny Afwadzi. Kompleks Makam Raja-Raja Mataram. Tanggal 12 Januari 2018. 
Lampiran (Daftar Penghuni Makam Seniman)

\begin{tabular}{|c|c|c|c|c|c|}
\hline No & $\begin{array}{c}\text { Hari/Tanggal } \\
\text { Pemakaman }\end{array}$ & Nama & Alamat & $\mathbf{L} / \mathbf{P}$ & Bidang Seni \\
\hline 1. & $\begin{array}{l}\text { Senin, } 19 \text { Februari } \\
1990\end{array}$ & Sudarmadji & Semarang & $\mathrm{L}$ & $\begin{array}{l}\text { Biolis dan Ketua orkes RRI } \\
\text { Semarang }\end{array}$ \\
\hline 2. & $\begin{array}{l}\text { Rabu, } 19 \text { Maret } \\
1991\end{array}$ & $\begin{array}{l}\text { Handung } \\
\text { Kusudiharjo }\end{array}$ & Yogyakarta & $\mathrm{L}$ & $\begin{array}{l}\text { Pelawak dan sesepuh } \\
\text { ketoprak Yogya }\end{array}$ \\
\hline 3. & $\begin{array}{l}\text { Selasa, } 1 \text { April } \\
1991\end{array}$ & Kusbini & Yogyakarta & $\mathrm{L}$ & Komponis 'Bagimu Negeri' \\
\hline 4. & Senin, 10 Mei 1992 & $\begin{array}{l}\text { Anastasia Surip } \\
\text { Suharto }\end{array}$ & Yogyakarta & $\mathrm{P}$ & $\begin{array}{l}\text { Pemain sinetron 'Jembatan } \\
\text { Mas' }\end{array}$ \\
\hline 5. & Selasa, 7 Juni 1992 & $\begin{array}{l}\text { Karnadji } \\
\text { Kristanto }\end{array}$ & Yogyakarta & $\mathrm{L}$ & Biolis \\
\hline 6. & Ahad, 18 Juni 1992 & $\begin{array}{l}\text { Maria Asumpta } \\
\text { Sudjilah } \\
\text { Handung } \\
\text { Kusudiharjo }\end{array}$ & Yogyakarta & $\mathrm{P}$ & $\begin{array}{l}\text { Isteri Pelawak dan sesepuh } \\
\text { ketoprak }\end{array}$ \\
\hline 7. & $\begin{array}{l}\text { Rabu, } 17 \\
\text { September } 1993\end{array}$ & Liberty Manik & Yogyakarta & $\mathrm{L}$ & $\begin{array}{l}\text { Komponis dan pencipta } \\
\text { lagu "Satu Nusa Satu } \\
\text { Bangsa" }\end{array}$ \\
\hline 8. & $\begin{array}{l}\text { Sabtu, 15 Januari } \\
1996\end{array}$ & Surip Suharto & Jakarta & $\mathrm{L}$ & Pemain sinetron \\
\hline 9. & $\begin{array}{l}\text { Kamis, } 23 \text { Februari } \\
1996\end{array}$ & $\begin{array}{l}\text { Hj. Suwarni } \\
\text { Widayat }\end{array}$ & Magelang & $\mathrm{P}$ & Isteri pelukis \\
\hline 10. & $\begin{array}{l}\text { Senin, } 21 \text { Maret } \\
1996\end{array}$ & M.P. Siagian & Yogyakarta & $\mathrm{L}$ & $\begin{array}{l}\text { Pencipta Lagu "Himne } \\
\text { Polri" }\end{array}$ \\
\hline 11. & $\begin{array}{l}\text { Rabu, } 27 \text { April } \\
1996\end{array}$ & $\begin{array}{l}\text { Sasminto } \\
\text { Dipuro }\end{array}$ & Yogyakarta & $\mathrm{L}$ & Penari \\
\hline 12. & $\begin{array}{l}\text { Kamis, } 20 \text { Agustus } \\
1997\end{array}$ & R. Harsoyo & Yogyakarta & $\mathrm{L}$ & Kepala Desa \\
\hline 13. & $\begin{array}{l}\text { Ahad, } 5 \text { September } \\
1997\end{array}$ & Nasyah Djamin & Yogyakarta & $\mathrm{L}$ & Sastrawan dan Pelukis \\
\hline 14. & $\begin{array}{l}\text { Selasa, } 1 \\
\text { September } 1998\end{array}$ & $\begin{array}{l}\text { Agustinus } \\
\text { Moralistyo }\end{array}$ & Yogyakarta & $\mathrm{L}$ & Pelukis \\
\hline 15. & $\begin{array}{l}\text { Selasa, } 12 \text { Oktober } \\
1999\end{array}$ & $\begin{array}{l}\text { M. Husni } \\
\text { Thamrin }\end{array}$ & Yogyakarta & $\mathrm{L}$ & Pelukis \\
\hline 16. & $\begin{array}{l}\text { Kamis, } 20 \text { Januari } \\
2000\end{array}$ & Kirdyomulyo & Yogyakarta & $\mathrm{L}$ & Sastrawan \\
\hline 17. & $\begin{array}{l}\text { Senin, } 20 \text { Maret } \\
2000\end{array}$ & $\begin{array}{l}\text { Imelda Maria } \\
\text { Tuti Aming } \\
\text { Prayitno }\end{array}$ & Yogyakarta & $\mathrm{P}$ & Pelukis \\
\hline 18. & $\begin{array}{l}\text { Kamis, } 7 \\
\text { September } 2000\end{array}$ & Sumini Widayat & Magelang & $\mathrm{P}$ & Isteri pelukis \\
\hline 19. & $\begin{array}{l}\text { Rabu, } 4 \text { Oktober } \\
2000\end{array}$ & $\begin{array}{l}\text { Rm. Soerono } \\
\text { Handronoto }\end{array}$ & Yogyakarta & $\mathrm{L}$ & Pelukis \\
\hline 20. & $\begin{array}{l}\text { Rabu, } 24 \text { Januari } \\
2001\end{array}$ & $\begin{array}{l}\text { R. Ay. Edy } \\
\text { Suminto }\end{array}$ & $\begin{array}{l}\text { Gunung } \\
\text { Sampu }\end{array}$ & $\mathrm{P}$ & Pelukis \\
\hline 21. & $\begin{array}{l}\text { Selasa, } 27 \text { Maret } \\
2001\end{array}$ & Saptoto & Yogyakarta & $\mathrm{L}$ & Pematung dan Pelukis \\
\hline 22. & $\begin{array}{l}\text { 22 Juni } 2002 \\
\text { (meninggal) }\end{array}$ & H. Widayat & Magelang & $\mathrm{L}$ & Pelukis \\
\hline 23. & Kamis, 26 Juni & Arman Kukuh & Yogyakarta & $\mathrm{L}$ & Seni musik \\
\hline
\end{tabular}




\begin{tabular}{|c|c|c|c|c|c|}
\hline & 2003 & Suparman & & & \\
\hline 24. & $\begin{array}{l}\text { Jum'at, } 3 \text { Oktober } \\
2003\end{array}$ & $\begin{array}{l}\text { KRT. RM. } \\
\text { Sapto Hoedoyo }\end{array}$ & Yogyakarta & $\mathrm{L}$ & Pendiri Makam/Pelukis \\
\hline 25. & $\begin{array}{l}\text { Senin, } 19 \text { Januari } \\
2004\end{array}$ & Fajar Sidik & Yogyakarta & $\mathrm{L}$ & Pelukis \\
\hline 26. & $\begin{array}{l}\text { Kamis, } 13 \text { Mei } \\
2004\end{array}$ & $\begin{array}{l}\text { R. Ay. Sri } \\
\text { Rudatin Soerono }\end{array}$ & Yogyakarta & $\mathrm{P}$ & Isteri Pelukis \\
\hline 27. & $\begin{array}{l}\text { Senin, } 7 \text { Maret } \\
2005\end{array}$ & Sri Suwartilah & Yogyakarta & $\mathrm{P}$ & Penari dan Pengrawit \\
\hline 28. & $\begin{array}{l}\text { Jum'at, } 26 \text { Agustus } \\
2005\end{array}$ & $\begin{array}{l}\text { Ngadiyem } \\
\text { Kusbini }\end{array}$ & Yogyakarta & $\mathrm{P}$ & Musik \\
\hline 29. & $\begin{array}{l}\text { Jum'at, } 16 \\
\text { Desember } 2005\end{array}$ & $\begin{array}{l}\text { Cicilius Tuwuh } \\
\text { Atmo Suwinto }\end{array}$ & Yogyakarta & $\mathrm{L}$ & Tidak diketahui \\
\hline 30. & $\begin{array}{l}\text { Kamis, } 22 \text { Juni } \\
2006\end{array}$ & Sudarso & Yogyakarta & $\mathrm{L}$ & Pelukis \\
\hline 22. & $\begin{array}{l}22 \text { Agustus } 1997 \\
\text { (meninggal) }\end{array}$ & $\begin{array}{l}\text { Hj. Aisyah } \\
\text { Sudarso binti } \\
\text { Yahya }\end{array}$ & Yogyakarta & $\mathrm{P}$ & Isteri pelukis \\
\hline 32. & $\begin{array}{l}\text { Selasa, } 26 \text { Juni } \\
2007\end{array}$ & $\begin{array}{l}\text { Nunuk Sri } \\
\text { Wahyuni Basuki } \\
\text { Ws. }\end{array}$ & Yogyakarta & $\mathrm{P}$ & $\begin{array}{l}\text { Isteri Pelukis dan Alumnus } \\
\text { ASRI }\end{array}$ \\
\hline 33. & $\begin{array}{l}\text { Jum'at, } 14 \text { Maret } \\
2008\end{array}$ & $\begin{array}{l}\text { Zeno Teguh } \\
\text { Suwarto }\end{array}$ & Yogyakarta & $\mathrm{L}$ & Pelukis \\
\hline 34. & $\begin{array}{l}\text { Senin, } 31 \text { Maret } \\
2008\end{array}$ & H. Suyanto & Yogyakarta & $\mathrm{L}$ & Tidak diketahui \\
\hline 35. & $\begin{array}{l}\text { Jum'at, } 5 \text { Desember } \\
2008\end{array}$ & Sudarso Sp. & Yogyakarta & $\mathrm{L}$ & Dosen Seni \\
\hline 36. & Selasa, 5 Mei 2009 & $\begin{array}{l}\text { KRT. } \\
\text { Soenartomo } \\
\text { Condro Radono }\end{array}$ & Yogyakarta & $\mathrm{L}$ & Penari \\
\hline 37. & $\begin{array}{l}\text { Selasa, } 10 \\
\text { Nopember } 2009\end{array}$ & $\begin{array}{l}\text { Kasman Kulin } \\
\text { Saerab }\end{array}$ & Yogyakarta & $\mathrm{L}$ & Seni Patung \\
\hline 38. & $\begin{array}{l}\text { Rabu, } 18 \text { Agustus } \\
2010\end{array}$ & H. Liau Sahar & Yogyakarta & $\mathrm{L}$ & Pelukis \\
\hline 39. & $\begin{array}{l}\text { Jum'at, } 14 \text { Januari } \\
2011\end{array}$ & Djamal Djaya & Yogyakarta & $\mathrm{L}$ & Seni Musik-Seni Rupa \\
\hline 40. & $\begin{array}{l}\text { Senin, } 13 \text { Februari } \\
2011\end{array}$ & M. Habib Bari & Yogyakarta & $\mathrm{L}$ & $\begin{array}{l}\text { Inisiator acara Kuncung } \\
\text { dan Bawuk }\end{array}$ \\
\hline 41. & Jum’at, 1 Juni 2012 & $\begin{array}{l}\text { Hj. Kustiyah } \\
\text { Edhi Sunarso }\end{array}$ & Yogyakarta & $\mathrm{P}$ & Pelukis \\
\hline 42. & $\begin{array}{l}\text { Jum'at, } 15 \text { Juni } \\
2012\end{array}$ & R. Sardjito & Yogyakarta & $\mathrm{L}$ & Pelukis \\
\hline 43. & $\begin{array}{l}\text { Rabu, } 30 \text { Januari } \\
2013\end{array}$ & $\begin{array}{l}\text { Hj. Sri } \\
\text { Sumaryatun } \\
\text { Saptoto }\end{array}$ & Yogyakarta & $\mathrm{P}$ & Isteri pelukis dan pematung \\
\hline 44. & $\begin{array}{l}\text { Sabtu, } 10 \text { Agustus } \\
2013\end{array}$ & $\begin{array}{l}\text { Bambang } \\
\text { Masrianto } \\
\text { Masroom Bara }\end{array}$ & Yogyakarta & $\mathrm{L}$ & Seni Teater \\
\hline 45. & $\begin{array}{l}\text { Sabtu, } 18 \text { Januari } \\
2014\end{array}$ & R. Suatmadji & Yogyakarta & $\mathrm{L}$ & Seni Lukis \\
\hline 46. & $\begin{array}{l}\text { Rabu, } 19 \text { Februari } \\
2014\end{array}$ & R. Sun Ardi & Yogyakarta & $\mathrm{L}$ & Seni Grafis \\
\hline 47. & $\begin{array}{l}\text { Senin, } 31 \text { Maret } \\
2014\end{array}$ & $\begin{array}{l}\text { Alexia Maria } \\
\text { Endang }\end{array}$ & Yogyakarta & $\mathrm{P}$ & Seni Tari \\
\hline
\end{tabular}




\begin{tabular}{|c|c|c|c|c|c|}
\hline & & Nrangwesti & & & \\
\hline 48. & $\begin{array}{l}\text { Selasa, } 5 \text { Januari } \\
2016\end{array}$ & H. Edhi Sunarso & Yogyakarta & $\mathrm{L}$ & Pematung \\
\hline 49. & $\begin{array}{l}\text { Kamis, } 19 \text { Mei } \\
2016\end{array}$ & Harsono Sapuan & Yogyakarta & $\mathrm{L}$ & Pelukis \\
\hline 50. & Sabtu, 28 Mei 2016 & $\begin{array}{l}\text { Mugiyah Arman } \\
\text { Kukuh } \\
\text { Suparman }\end{array}$ & Yogyakarta & $\mathrm{P}$ & $\begin{array}{l}\text { Isteri dari Pemusik Arman } \\
\text { Kukuh Suparman }\end{array}$ \\
\hline 51. & Rabu, 15 Juni 2016 & $\begin{array}{l}\text { KRT. Soesanto } \\
\text { Gunoprawiro }\end{array}$ & Yogyakarta & $\mathrm{L}$ & $\begin{array}{l}\text { Pelawak } \\
\text { Pemusik }\end{array}$ \\
\hline 52. & $\begin{array}{l}\text { Ahad, } 6 \text { Nopember } \\
2016\end{array}$ & $\begin{array}{l}\text { Hasmi (Haryo } \\
\text { Suro Amijoyo) }\end{array}$ & Yogyakarta & $\mathrm{L}$ & $\begin{array}{l}\text { Komikus } \\
\text { Perupa }\end{array}$ \\
\hline 53. & Sabtu, 8 Juli 2017 & $\begin{array}{l}\text { Susapto } \\
\text { Murdowo }\end{array}$ & Yogyakarta & $\mathrm{L}$ & Seni Lukis \\
\hline 54. & $\begin{array}{l}\text { Sabtu, } 23 \\
\text { September } 2017\end{array}$ & $\begin{array}{l}\text { Ki Ledjar } \\
\text { Soebroto }\end{array}$ & Yogyakarta & $\mathrm{L}$ & Dalang Wayang Kancil \\
\hline 55. & $\begin{array}{l}\text { Selasa, } 12 \\
\text { Desember } 2017\end{array}$ & Bayu Bintoro & Yogyakarta & $\mathrm{L}$ & Kepala Desa \\
\hline
\end{tabular}

